\title{
Die slag toe slim sy baas gevang het ${ }^{1}$
}

\section{Christo van Rensburg}

Navorsingseenheid Tale en literatuur in die SA konteks. NWU, Potchefstroom-Kampus. Suid-Afrika. E-pos: christovanrensburg100@gmail.com

\begin{abstract}
The day when the clever arguments misfired. Some very interesting observations can be made in describing the history of the standardising of Afrikaans. It is possible that the plans that Lord Milner had in mind for the establishing of an exclusive English language in South Africa during the early years of the twentieth century could be the starting point of Afrikaans as an official language some two decades later.
\end{abstract}

Afrikaans was a well-known spoken language by 1910. It started with the Khoi, using their language as a base, and then adapting the language of the seafarers on the Dutch ships, which they construed as a new trade language: Afrikaans. This language later became one of the main languages of the central parts of South Africa. The sheep and cattle farmers from the interior spoke a language that was far removed from Dutch as well. These two Afrikaans dialects were not used for higher functions, and they influenced each other to a great extent.

The tradition among speakers of Afrikaans of using Dutch whenever the written functions of Dutch were required was one of the main deterrents for broadening the scope of Afrikaans. Dutch was used in the public schools with little success, largely due to Dutch not being a home language for the Afrikaans scholars attending those schools. In fact, Dutch was hardly a spoken language in South Africa, but it was a language with well-established higher functions, which Afrikaans lacked. In this context, the use of Dutch in schools prevented mother-tongue speakers of Afrikaans' education in their mother tongue.

Emphasising the need for Afrikaans as a medium of instruction for Afrikaans-speaking pupils, Langenhoven used some clever arguments to gain the support in 1914 of the Dutch-oriented South African Academy for Language, Literature and Art (Zuid-Afrikaansche Akademie voor Taal, Letteren en Kunst) for his plan to introduce Afrikaans as a language of choice in the public schools where Dutch was taught as well. Rather unexpectedly, the Academy supported his plan.

It appears that Langenhoven struck a deal with the pro-Dutch language association, the ZuidAfrikaansche Taalbond, beforehand, which left the Afrikaans language commission no other option but to use Dutch spelling rules to spell Afrikaans.

\footnotetext{
1 'n Uitgebreide en verwerkte weergawe van die Suid-Afrikaanse Akademie vir Wetenskap en Kuns se J. B. M. Herzoggedenklesing Toe die maak van die Afrikaanse woordelyste \& spelreëls ook perdekoop was (13/09/17).
} 
The direct outcome of this arrangement is discussed here, as well as some of the consequences following from it.

Keywords: early Afrikaans dialects, official language, standard Afrikaans, the Afrikaanse Woordelys en Spelreëls, the South African Academy for Science and Arts.

Trefwoorde: amptelike taal, die Afrikaanse Woordelys en Spelreels, die Suid-Afrikaanse Akademie vir Wetenskap en Kuns, Standaardafrikaans, vroeë Afrikaanse dialekte.

\section{Inleiding}

Die Afrikaanse Woordelys en Spelreëls (AWS) is een van die invloedrykste boeke in Afrikaans omdat dit sedert 1917 al vir 100 jaar lank aandui hoe Standaardafrikaans behoort te lyk wanneer omstandighede die gebruik van daarvan regverdig.

Die wordingsgeskiedenis van die Afrikaanse Woordelys en Spelreëls vertel 'n interessante verhaal van besondere inisiatiewe en van verskeie planne vir die skryf van Afrikaans van die begin van die twintigste eeu af. In een van die episodes, wat besondere nagevolge vir veral geskrewe Afrikaans gehad het, het dit gelyk of C. J. Langenhoven met slim maneuvers sy sin gekry het om Afrikaans in 1914 te laat reglementeer. Dit was op die ou einde nie die geval nie. Slim het sy baas gevang, want dit was nie Afrikaans wat by sy inisiatief gebaat het nie, maar 'n vernederlandse taalvorm onder die naam van Afrikaans. Die Taalkommissies wat die spelling en skryfwyse van Afrikaans in die daaropvolgende $A W S^{\prime}$ e bereël het, het dié taalvorm daarna voortdurend verafrikaans. Langenhoven se offensief word hier bespreek. Dit het op 23 April 1914 begin toe hy 'n vernuftige veldtog geloods het om Afrikaans as skooltaal tot standerd 4 (graad 6) in die Provinsiale skole ingevoer te kry, en het afgeloop toe De ZuidAfrikaansche Akademie voor Taal, Letteren en Kunst (die Akademie) op 3 Julie 1914 besluit het om verantwoordelikheid te aanvaar vir die standaardisering van Afrikaans. (Die verloop van daardie proses word uiteengesit in Van Rensburg 2017b.)

\section{Die begin van die eerste Afrikaanse Woordelys en Spelreëls?}

Die aanleiding tot die kodifisering van Afrikaans kan teruggevoer word na die taalsituasie in Suid-Afrika, so 'n dekade of wat voordat daar in 1914 met die standaardisering van Afrikaans 'n aanvang geneem is. Die taalplan wat Lord Alfred Milner na afloop van die AngloBoereoorlog (1899-1902) vir Suid-Afrika voor oë gehad het, het 'n Engelse Suid-Afrika behels (Spies 1968: 323), maar sy plan het tot 'n einde gekom toe die Konserwatiewe Party in Brittanje in 1905 uit die kussings gelig is. Die Liberale Party het Milner se taalambisies met hulle bewindaanvaarding ongedaan gemaak.

Polities het Suid-Afrika in 1910 'n Unie geword, en anders as wat dit met die vorige taalbereëling die geval was, is daar toe ruimte geskep vir 'n taal van die inwoners van die land wat as mede-ampstaal naas Engels 'n rol in Suid-Afrika kan speel. Met dié besluit is 'n gaping gelaat vir die moontlike ampstaalwording van Afrikaans (Van Rensburg 2017a: 252). Dit sou sy standaardisering behels, en die saamstel van 'n Afrikaanse Woordelys en Spelreëls waarin sulke reglementeringsriglyne vervat kon word. Maar om in 1905, met die 
regeringsverandering in Brittanje, vir Afrikaans 'n posisie van mede-ampstaal te voorsien het, was baie voortydig.

\section{Afrikaans of Nederlands?}

Watter groep Suid-Afrikaners se taal sou die funksie van mede-ampstaal na 1910 uitvoer? 'n Kyk na daardie taalsituasie, wys heelwat van die taalstrominge uit wat vir 'n lang tyd die taaltoneel van die nuwe Unie van Suid-Afrika oorheers het.

Gesien die landswye bekendheid van Afrikaans teen 1910 (Steyn 2014: 41), sou dié taal dalk oorweeg kon word as mede-ampstaal. Khoi-Afrikaans, en die Afrikaans van die vee- en trekboere op die voorposte en in die binneland, wat ver van versorgde Nederlands af gestaan het, was teen die tyd van uniewording in 1910 al lankal die taal met die wydste verspreiding van al die tale van Suid-Afrika. Burchell (1967 I: 29, 77), het aan die begin van die negentiende eeu opgemerk hoe uitgebreid Afrikaans oor Suid-Afrika gepraat is, en het genoem dat reisigers byvoorbeeld aangeraai is om ten minste 'n rudimentêre kennis van Afrikaans te verwerf voordat hulle die binneland aangedurf het. Viljoen het agtergekom dat Afrikaans die "eigentliche Form der südafrikanischen Umgangs- und Volkssprache" is. In 'n Mededeling in die Pall Mall Gazette van 4 Junie 1894 het hy ondersteuning vir sy waarneming in 'n anonieme skrywer se bydrae gekry, wat geskryf het: "that language [Afrikaans] has permeated all South Africa" (Viljoen 1896: 24-25).

Verder het Afrikaans ook 'n lang geskiedenis in Suid-Afrika gehad. In die vyftig jaar na 1595, voordat die VOC-verversingstasie aan die Kaap gestig is, het die Khoi-Khoin Afrikaans al as 'n handelstaal gebruik toe hulle met die Nederlandse seevaarders handel gedryf het. Hulle het môre sonder die -g- uitgespreek, soos in latere Afrikaans, en gee en maak is toé ook opgeteken (vgl. Van Rensburg 2016 vir meer besonderhede). Indien die data oor die KhoiKhoin se aanleerderstaal vóór die stigting van die verversingspos in 1652 nie in berekening gebring word nie, dateer Ponelis (1993: 158) die vroegste optekenings van Afrikaanse woorde sonder -g-, waar Nederlands dit wel het, as 1719, en Raidt (1983: 85) gee die datum van die eerste optekening van gee aan as 1812. In die agtiende eeu het omstandighede daartoe meegewerk dat die Khoi van die vroeë inwoners van die Kaap deur 'n proses van taalverplasing vervang is, en dat hierdie aanleerderstaal, Khoi-Afrikaans, 'n moedertaal geword het. Khoi is gaandeweg net op die periferie van die agtiende-eeuse taalkontaksituasies gehoor.

Afrikaans se funksies was egter beperk, hy was 'n gesprekstaal, en het nie hoë status geniet nie. Waar Afrikaans in die negentiende eeu wel geskryf is, was daardie skryftaalvoordele beperk tot kleiner gemeenskappe. Dié pogings tot verskrifteliking van Afrikaans het in die loop van die negentiende eeu doodgeloop, en die Genootskap van Regte Afrikaners se verdienstelike poging om húlle Afrikaans van 1875 af te skryf, het teen die eeuwending ook begin versand (Steyn 1914: 42). Daardie geskrewe GRA-Afrikaans, soos gesproke Afrikaans in die algemeen, was in vergelyking met Hollands ${ }^{2}$ nie hoog gewaardeer nie. "Van kleins af word dit Afrikaners met lepels ingegee dat die beskaafde taal Hoog-Hollands is en dat Afrikaans veragtelik is", het Langenhoven in 1910 geskryf (Langenhoven 1910: 16-18). Dit is te begrype dat Afrikaans nie in 1910 die mede-ampstaal geword het nie. Om 'n taal 'n (mede-

\footnotetext{
${ }^{2}$ Voor 1930 is daar meestal van Hollands gepraat, en dié gebruik word hier gevolg. Waar Nederlands wel in tekste voorkom, word daarby aangesluit, soos ook by die name van die vier Provinsies.
} 
)ampstaal te maak, moes weldeurdagte planne beraam word en 'n breë steunbasis gekonsolideer word (vgl. Steyn 1980: 78 oor die verloop van so 'n aksie), en daar was teen 1910 nie genoeg taalaktiviste vir Afrikaanse wat suksesvol met die voorstanders van Nederlands kon kompeteer nie.

Die bestaan van Hollandse onderwysmateriaal, Hollandse media, asook die gedugte organisasie wat Hollands in Suid-Afrika bevorder het, Die Zuid-Afrikaansche Taalbond (vgl. Steyn 2017 oor die Taalbond), het daaraan meegewerk dat geskrewe Hollands 'n hoë status geniet het (Voorbericht in Elffers en Viljoen 1908). Die taalaktiviste wat wel taalambisies vir Afrikaans gekoester het, is gemaklik op die agtergrond gehou deur die bestaande Hollandse infrastruktuur en die status wat aan die taal gekoppel is. Al was daar min Hollandssprekends in Suid-Afrika, kon die voorstanders van Hollands hulle op besluitnemingsvlak laat geld, en sonder moeite daarin slaag om Hollands mede-ampstaal in Suid-Afrika te maak toe die geleentheid hom voorgedoen het. Hollands as mede-ampstaal het die voortsetting van Hollands as skooltaal beteken, en Hollands as mediataal (waar dit nie Engels was nie), en Hollands op talle ander aansluitende taalfronte.

Afrikaanssprekende politici se sukkelende Hollands het die beperkte gebruik van Hollands in Suid-Afrika goed geïllustreer. Langenhoven kon die versoeking nie weerstaan het om L. Botha, die Eerste Minister van die Unieregering na 1910, oor sy gebrekkige Hollands te hekel nie. "Die generaal gebruik ... [in sijn toesprake] nie 'n Hollands wat met die taal van 'n Hollander maklik kan verwar word nie, maar 'n soort Afrikaans met hollandse verbuiginge wat hij sonder 'n bepaalde plan holderste bolder inlas sodat daar nou en dan bij toeval een op die regte plek kom" (het Kannemeyer 1995: 302 hom aangehaal). Botha was een van 'n groot groep parlementariërs wat nie Hollands kon praat nie, en wat Langenhoven, ook 'n lid van die parlement, raakgesien het: 'Since I have been a member of this House I have not heard a single non-English speech delivered in any other language than in Afrikaans, though I have heard some bad Afrikaans which was intended to be High Dutch' het hy gesê (Kannemeyer 1995: 435).

Nederlands as skooltaal het na 1910 owerheidssteun geniet, maar was nogtans nie 'n sukses nie (Zietsman 1992: 139-140). Een van die hoofredes daarvoor was dat Hollands nie as huistaal gebruik is nie. Prof. W. J. Viljoen, van die Taalbond, wou Hollandsonderrig in SuidAfrika 'n hupstoot gee deur dit makliker te maak vir die Afrikaanssprekende leerlinge. Die algemene gebruik van Hollands kon daardeur ook bevorder word, en Afrikaans sou op die agtergrond bly. In 1903 het hy in Nederland en België onderhandel om die Vereenvoudigde Hollandse spelling (VHS), volgens die Kollewijn-spelmanier, ook in Suid-Afrika te gebruik. Sy ondersteuning van die vereenvoudigde Hollandse spelling het meegebring dat D. B. Bosman, wat vir 40 jaar lank 'n Taalkommissielid was, na Viljoen verwys het as die "hoëpriester" van die Vereenvoudigde Hollandse Spelling (VHS) in Suid-Afrika (Bosman 1959: 77). Tydens daardie 1903-besoek van Viljoen aan Nederland en België, het die Kollewijn-spellers aan hom toestemming gegee om enkele Afrikaanshede in Suid-Afrika se Hollands toe te laat, maar dan moes die taal en spelling steeds Nederlands bly. Die opstellers van die bekende en invloedryke Vereenvoudigde Hollandse-woordeboeke vir gebruik in SuidAfrika, Elffers en Viljoen (1908), en Van Rijn (1908), het hierdie riglyn voortreflik geillustreer. Hulle het min Afrikaanse woorde in hulle werke opgeneem, en dit duidelik as Afrikaans gemerk. 
Op 'n indirekte manier is nóg funksies van Nederlands beskerm, deurdat die nieEngelssprekende lede van die Regering hulle vir die gelykberegtiging tussen Engels en Nederlands beywer het. Gelyke behandeling van dié twee tale was nie 'n vanselfsprekende saak nie, al het Artikel 137 van die Unie-Grondwet dit verwag. "Tydens Botha en Smuts se regerings was tweetaligheid in die staatsdiens maar 'n dooie letter en is mense wat op hul taalregte aangedring het, soms brutaal beledig”, laat Kannemeyer (1995: 427) hom oor dié saak uit.

Die gesprek oor gelykberegtiging wat dit ten doel gehad het om die regte van Nederlands in Suid-Afrika na 1910 te beskerm, en dit het die hoëvlakbesluitnemers se aandag afgetrek van die groeiende behoefte van die sprekers wat hulle met Afrikaans wou identifiseer. Dit het nie gelyk asof Afrikaans se funksies uitgebrei sou word, en dat hy as 'n afsonderlike taal erken sou word nie, selfs nie toe Afrikaans na die Rebellie van 1914 'n merker van talle van sy sprekers se nasionale mondering geword het nie.

Die naspel van die Rebellie het 'n nasionale gevoel aangewakker wat baie wyer gereik en baie meer mense betrek het as net die deelnemers aan die Rebellie en hulle families. Ponelis noem daardie nasionalisme, wat op ander maniere ook aangewakker is, "[d]ie belangrikste sosiale dryfkrag agter ... die ... kultivering van Afrikaans (Ponelis 1992: 72). In latere dekades, van 1950 af, het Afrikaans swaar begin dra aan die koppeling van die Nasionale Party met die taal. In die loop van die 20ste eeu is Afrikaanssprekendes "as rassepatriotte gevorm ... en [is] 'n aggressiewe nasionalisme aangewakker" (Pretorius 2012: 254). In die verbintnis van die Nasionale Party met Afrikaans kon ondertone van eiendomlikheid waargeneem word, hoewel taal nie besit kan word nie. Ponelis maak daarvan melding dat alternatiewe uitsprake oor Afrikaans ook voorgekom het, wat Afrikaans as 'n taal gesien het, en nie as 'n politieke instrument nie (Ponelis 1993: 60).

Op 'n direkte manier het die owerheid ook vir Hollands in die bresse getree wanneer kwessies oor taal in die onderwys die aandag geverg het. J. C. Steyn het in 'n persoonlike mededeling daarop gewys dat dit een van die eerste sake was wat die Unieparlement se aandag geniet het. Ná Uniewording het hierdie taalbemoeienis, gerugsteun deur artikel 137 van die grondwet, gesorg vir betekenisvolle wysigings ten gunste van Hollands in die voertaalbeleid van die hoër- en laerskole wat onder staatsbeheer was.

Die Unieparlement se belang by die kwessie van taal in die onderwys het uitgeloop op verskeie moedertaalordonnansies waarvan Langenhoven later deeglik kennis geneem het. Spies (1968: 331) wys daarop dat J. C. Smuts in 1907 in Transvaal met onderwyswetgewing oor Hollands en Engels 'n aanvang geneem het. Daarvolgens is moedertaalonderrig in Hollands tot standerd 4 moontlik gemaak (met onderrig daarna in Engels), en J. B. M. Hertzog het in 1908 Hollands en Engels in 'n onderwyswet in die Vrystaat gelykgestel. Die Unieparlement se belang by die kwessie van taal in die onderwys (vestig J. C. Steyn my aandag op) het uitgeloop op die moedertaalordonnansies wat in Transvaal in 1911, en in die Vrystaat en Kaapland in 1912, die skooltaal bereël het. Dié ordonnansies het die verskansing van Nederlands as skooltaal in die oog gehad, en nie die uitbouing van Afrikaans nie.

Langenhoven het bewus geword van 'n gevoeligheid wat onder Afrikaanssprekendes geheers het oor die ondersteuning van Hollands as skooltaal. Omdat Afrikaanssprekende kinders nie Hollands geken het nie, het dit grootliks daartoe bygedra dat hulle skoolprestasies uiters swak 
was (Zietsman 1992: 82-83). Selfs die vereenvoudigde vorm van Hollands (VHS) kon nie by die Afrikaanssprekende skoliere geesdrif vir Nederlands opwek nie. Hulle negatiewe ingesteldheid teenoor Hollands op skool het onderwysstruikelblokke onnodig vergroot: 'n Briefskrywer aan Ons Land het in 1910 byvoorbeeld van die Hollandse lidwoordgebruik gepraat as die "verschrikkelikheden van 'de', 'den' en 'het'” (aangehaal deur Steyn 1989: 218).

\section{4. 'n Oplossing?}

Langenhoven het hierdie sukkelgang van Nederlands as skooltaal as 'n regverdiging gesien om die bestaande skooltaalpraktyk wat op die beskerming van Hollands gerig was, te wysig. Waarom nie by die kern van die probleem uitkom en ruimte skep vir Afrikaans as skooltaal naas Hollands nie? Al die bestaande reëlings om Hollands te ondersteun, het mos nie beteken dat hy Afrikaans nie ook by die gesprek kan betrek nie? Langenhoven se optrede kan begryp word teen die agtergrond van sy uitlating (waarna Kannemeyer 1995: 241 verwys): "As Nederlands ons taal is, waarom praat ons hom nie? As Afrikaans ons taal is, waarom skryf ons hom nie?" Sy taalplan vir Afrikaans as skooltaal het die patroon van die Hollands-asskooltaal-tot-standerd 4-ordonnansies, netjies gevolg, maar met die verskil dat hy Hollands met Afrikaans vervang het. Hy wou in 1914, in die jaar van die Rebellie, sy nuwe taalplan in twee fases in werking stel. Vir die eerste fase daarvan moes hy by die Provinsiale Regerings toestemming kry dat Afrikaans as skooltaal gebruik kan word, en as hy daarvoor goedkeuring gekry het, moes hy 'n instansie oorreed om dié plan uit te voer.

Langenhoven het in 1914 'n lid van die Kaapse Provinsiale Raad geword, en het van die geleentheid gebruik gemaak om dié Raad se goedkeuring vir sy plan te kry. Op 23 April 1914 het hy 'n voorstel daaroor aan die Kaapse Provinsiale Raad voorgelê.

Die Langenhoven-skooltaalplan het nie net die Kaapse Provinsiale Raad onverwags getref nie, maar het ook soos 'n rukwind deur die Afrikaanse Taalwêreld gewaai. G. S. Nienaber (Nienaber 1959: 37) het sy optrede 'n verassingsaanval genoem. Die vooruitsigte dat sy plan kon slaag? Dit was nie "rooskleurig" nie, het Langenhoven self toegegee (Kannemeyer 1995: 291). Hy is voor die tyd aangeraai om met sy plan te wag totdat Afrikaans verder sou ontwikkel (Steyn 2014: 127). Maar Langenhoven was nie 'n man wat hom sommer laat aanraai het nie. Dit kan ook bevraagteken word of 'n taal tot skooltaal uitgebou kan word as taalaktiviste hulle nie daadwerklik daarvoor beywer nie, nadat hulle natuurlik ook goed nagedink het oor die tydsberekening van hulle aksie.

Langenhoven het sy vinger nie presies op die pols van Afrikaans gehad nie. Hy was nie voor sy plan om Afrikaans tot skooltaal te verhef, 'n voetsoldaat vir Afrikaans nie, en het aan geen Afrikaanse vereniging behoort nie. Sou hy 'n goeie aanvoeling vir die regte tydsberekening vir die uitvoer van sy plan gehad het? kan met reg gevra word. In 1913 het hy 'n Akademielid geword, en is op grond van sy pro-Engelse optrede voor die tyd selfs beskryf as 'n Anglofiel (Giliomee 2009: 258). Vir die geskiedenis van Afrikaans is dit van belang dat Langenhoven waarskynlik die eerste taalaktivis vir Afrikaans was "wat van die keuse tussen Afrikaans en Hollands 'n politieke kwessie gemaak het” (Steyn 1989: 219-220).

Langenhoven het op 'n interessante manier te werk gegaan om sy sin te kry oor die invoer van Afrikaans as skooltaal tydens die vergaderings van die Kaapse Provinsiale Raad. Hy het voor 
die tyd, buite die vergaderings en voordat hy sy voorstel voorgelê het, met lede van die Raad daaroor gesprekke gevoer, en baie klem op moedertaalonderrig gelê. Die krag van sy buitevergaderingse gesprekke was nie te onderskat nie. Die Kaapse Provinsiale Raad het sy voorstel sonder teenstem aanvaar, maar van Langenhoven verwag om 'n teenprestasie te lewer: Hy moes waarborge lewer dat sy plan uitvoerbaar was. Dit het meegebring dat hy moes sorg vir die

(i) ondersteuning vir die invoer van Afrikaans as skooltaal tot op standerd 4 (graad 6),

(ii) die voorsiening van onderwysmateriaal in Afrikaans, en die gehaltekontrole daarvan, en

(iii) die totstandbringing van 'n standaardiseringskommissie vir Afrikaans - die latere Taalkommissie.

Die Vrystaatse en Transvaalse Provinsiale Rade het soos die Kaapse Provinsiale Raad die Langenhovenvoorstel in 1914 ondersteun, en waarborge vir die uitvoerbaarheid daarvan as voorwaarde gestel,

Hoe was dit met Natal gesteld? Geskiedenisbronne vermeld eerder die invoerdatum van Afrikaans as skooltaal in die drie ander provinsies as Natal. Daar het dit eers twee jaar later, in 1916 gebeur, skryf J. C. Steyn in 'n persoonlike mededeling. "In 'n hoofstuk deur B. R. Buys oor onderwys in Natal wat deel is van J. Chr. Coetzee (redakteur) se Onderwys in Suid-Afrika 1652-1960 word verklaar dat Natal in 1916 'n ordonnansie gekry het wat ouers in Natal die reg gegee het om te kies of hulle kinders deur middel van 'Afrikaans of Engels' as voertaal onderrig moet kry".

Die instansie wat die waarborge moes verskaf dat die besluit oor die invoer van Afrikaans as onderrigtaal tot standerd 4 geïmplementeer kan word? Die Kaapse Provinsiale Raad het die Onderwysdepartemente van die onderskeie Provinsies daarvoor in gedagte gehad. Langenhoven het verkies dat die Akademie, waarvan hy al 'n jaar lank lid was, as die waarmerkliggaam optree. Dit is moontlik dat daar maar min lede van die Kaapse Provinsiale Raad bewus was van die bestaan van Akademie wat vyf jaar vantevore, in 1909, in Bloemfontein gestig is. Maar die Akademie het 'n indrukwekkende naam gehad: de ZuidAfrikaansche Akademie voor Taal, Letteren en Kunst, en die Provinsiale Raad het verlief geneem met Langenhoven se voorkeurkeuse. Die Akademie moes egter nog oorreed word om hierdie fase van Langenhoven se plan te steun.

Op 3 Julie 1914 het die Akademie na 'n voorstel van Langenhoven, en 'n indrukwekkende oorredingstoespraak deur hom, besluit om by Langenhoven se plan vir die invoer van Afrikaans as skooltaal in te val, en om die gevraagde waarborge aan die Provinsiale Rade te lewer. Langenhoven en sy medewerkers, waaronder T. H. le Roux (Akademiejaarboek V 1914: 88; Le Roux 1926: 270), het voor die tyd weer buite die Jaarvergadering met lede daaroor gesprekke gevoer (Akademiejaarboek V 1914: 141-143). Dit was slegs 123 dae (vier maande) nadat hy met sy plan begin het. 'n Suksesverhaal. Die verrassingsaanval waarvan Nienaber 1959 gepraat het, was ook 'n blitsoffensief, en Afrikaans het 'n skooltaal geword.

Die Akademiesekretaris het aan die Provinsiale Rade geskryf dat die Akademie die verantwoordelikheid vir die invoer van Afrikaans as skooltaal aanvaar (Akademiejaarboek V 1914). In sy Voorwoord tot die Afrikaanse Woordelijs en Spelreëls AWS 1 (1917) sinspeel Le Roux ook op die Akademie se aanvaarding van die Provinsiale Rade se voorwaardes. Hy 
maak herhaaldelik melding van die $A W S$ se belangrikheid vir die onderwys. Dit was immers die invoer van Afrikaans as skooltaal wat Langenhoven se voorstel aan die Kaapse Provinsiale Raad onderlê het. Le Roux oorbeklemtoon ook die eenvormigheid wat die skryftaal sou bereik het, soos wat die Provinsiale Raad van die Akademie verwag het. Gesien al die wisselvorme in $A W S$, is hierdie doelwit toe nog nie bevredigend bereik nie. Hy deel nie net in sy Voorwoordkode aan die Provinsiale Raad mee dat die Akademie wel die voorwaardes nagekom het vir die gehaltekontrole van Afrikaans as onderwystaal nie, maar bevestig dat 'n standaardiseringsliggaam vir Afrikaans funksioneer, soos wat die Provinsiale Raad wou gehad het.

Le Roux praat ook in die Voorwoord van $A W S 1$ van die opdrag wat van die Akademie af uitgegaan het vir die opstel van die Woordelys en Spelreëls. Waarmee hy te kenne gee dat die Akademie gesag het, en dat dit nie sommer 'n hierjy-groepie was wat Langenhoven aan die Engelse Kaapse Provinsiale Raad uitgeveil het, toe hulle eerder met die onderwysdepartement wou onderhandel het nie.

\section{Puntjie by paaltjie?}

Langenhoven het die Kaapse Provinsiale Raad betreklik maklik oorreed om sy standpunt oor die invoer van die onderrig van Afrikaans op skoolvlak te steun, en toe hy op 3 Julie 1914 by die Akademie ondersteuning daarvoor gevra het, was daar net twee teenstemme. In die aanloop tot die Akademievergadering het Langenhoven verskeie onderhandelings gevoer, en hom vooraf van baie lede se steun verseker. Wie sou teen so 'n skynbaar afgehandelde saak stem?

Dit is nogtans merkwaardig dat Langenhoven suksesvol by die Akademie aangeklop het om sy plan oor die invoer van Afrikaans as skooltaal te ondersteun. Die Akademie was 'n Nederlandsgesinde belangegroep wat as die kultuurarm van Nederlands in Suid-Afrika opgetree het nadat Nederlands die nuwe mede-ampstaal met Uniewording in 1910 geword het. Die liggaam moes onder andere sorg vir die bewuswording van Nederlandse romans, gelykberegting van Nederlands en Engels, en moes ook ander sake ten behoewe van Nederlands hanteer.

Die Hollandsgesinde taalvereniging, die Taalbond, was die dryfkrag agter die onderrig van Hollands in Suid-Afrika, en het 'n belangrike rol in die Akademie gespeel. Die Akademie het ook vir die Taalbond sy Nederlandse taalbondeksamens afgeneem. In Maart 1921, in 'n oorsig oor die Akademie se prestasies, maak die Akademiesekretaris melding van "hoe 'n belangrijk en voornaam onderdeel van de Zuidafrikaanse Akademie vormt de Taalbond" (Akademieargief, AREA, korrespondensie van Akademiesekretaris).

Was daar nie 'n vangplek ingebou in hierdie ondersteuning van die Akademie aan die Langenhovenplan nie? Hoekom sou die pro-Nederlandse Taalbond toesien dat Afrikaans as 'n skooltaal ingevoer word, wat sou meegebring het dat die gesukkel met Nederlands op skool slegs nog kon vererger het? As die Taalbond Langenhoven se voorstel tydens die Akademievergadering van 3 Julie 1914 teengestaan het, sou mens hulle standpunt goed kon begryp het. Afrikaans is in 1914 nie gesien as 'n taal van kulturele betekenis nie, en Elffers en Viljoen, wie se belangrike woordeboek in die Vereenvoudigde Hollandse Spelling in 1908 verskyn het, het in hulle voorwoord na Afrikaans verwys as 'n blote spreektaal. 
Prof. W. J. Viljoen, een van die opstellers van die genoemde Elffers en Viljoen-woordeboek, was professor in Hollands aan die Universiteit van Stellenbosch, en die krag agter die Taalbond. Langenhoven moes aan wonderwerke geglo het om te dink Viljoen sou sy greep op die Nederlandse onderwys verslap en plek maak vir die onderrig van Afrikaans. En dan moet mens onthou dat party van die Taalbondmanne ook nog finansieel gebaat het by die skryf van skoolmateriaal, soos Viljoen self meegedeel het (Kannemeyer 1995: 450).

Langenhoven was vroeër nie seker of die Kaaplandse Provinsiale Raad sy voorstel sou aanvaar om die eerste fase van sy plan in werking te stel nie. Hulle het dit wel gedoen. Toe hy sy voorstel aan die Akademie voorgelê het, was sake anders gesteld. Nou móés sy voorstel eenvoudig slaag. Dit sou die pro-Hollandse faksie in die Akademie gewees het wat teen sy voorstel sou stem, en die Akademie sou 'n hervoorstel nie weer toelaat nie, omdat hy hom juis vir die wankelrige eenheid tussen Afrikaans- en Hollandssprekendes beywer het (Kapp 2009: 24). Melt Brink wou drie jaar vóór Langenhoven, in 1911, 'n voorstel laat dien dat die Akademie gestandaardiseerde spelreëls vir Afrikaans opstel (Van Rensburg 2017a: 262). Die Akademie wou dié voorstel nie toelaat nie, omdat dit onmin tussen die twee groepe sou aanblaas (Kapp 2009: 111). Vir Langenhoven was daar geen omdraaikans nie. Die tweede fase van sy plan móés slaag, andersins sou die standaardisering van Afrikaans op die lange baan geskuif word, en wie weet wat dan van die standaardisering van Afrikaans sou word? Watter toegewings het Langenhoven gemaak om die vrede te bewaar wanneer sy voorstel bespreek word?

Toe Langenhoven in sy oorredingstoespraak tydens die Akademievergadering van 3 Julie by die spelreëls uitgekom het, het hy dit duidelik gestel dat geen veranderings, behalwe redaksionele wysigings, daaraan aangebring mag word nie (Akademiejaarboek V 1914: 88). Net na die toespraak het die Akademievergadering 'n Spelling-Kommissie (die eerste Taalkommissie) aangewys om die spelreëls binne 'n jaar aan hulle voor te lê vir goedkeuring (Akademiejaarboek V 1914: 88). Vir Langenhoven het die verdere werk aan die spelreëls, volgens sy 3 Julie-toespraak van 1914, hoofsaaklik die redaksionele versorging van die daardie reëls beteken. Die spelreëls vir die VHS wat voor in Elffers en Viljoen (1908, ongenommerde bladsy) opgeneem is, was heelwaarskynlik van groot hulp vir die SpellingKommissie: Daar bestaan 'n groot ooreenkoms tussen daardie VHS-spelreëls en die spelreëls van die Spelling-Kommissie. Op 18 September 1915 het die Spelling-Kommissie die spelreëls afgehandel. 'n Woordelys is daarna tot die Spelreëls toegevoeg om die reëls te illustreer, en behalwe vir 'n interne publikasie daaroor in 1917 deur Die Samestellers van die Woordelys, het die eerste $A W S$ in 1917 verskyn.

\section{Die vierde grondbeginsel van $A W S 1$}

In die eerste Afrikaanse Woordelys en Spelrë̈ls het die uitkomste van Langenhoven se onderhandelings hulle eerste lewenslig aanskou. Die Taalkommissie wat die eerste Afrikaanse Woordelys en Spelreëls opgestel het, het die spelreëls op vyf grondbeginsels gebaseer.

Die vierde grondbeginsel het laat blyk dat al die onderhandelinge met die Akademielede vóór die 3 Julie-vergadering nie so Afrikaans-vriendelik verloop het as wat Langenhoven dit wou gehad het nie. Daardie grondbeginsel het ook aangedui waarom W. J. Viljoen van die Taalbond die hoëpriester van die Vereenvoudigde Hollandse Spelling genoem is. Die enigste vetgedrukte grondbeginsel in $A W S$, om sy belangrikheid aan dui, gaan nie oor Afrikaans nie, 
maar lui dat Afrikaans "so weinig moontlik van die Vereenvoudigde Hollandse Spelling" sal afwyk. Daardie grondbeginsel het verwag dat Afrikaans soos Hollands gespel moet word en het die toegewings gewys wat Langenhoven gemaak het voordat die akademievergadering plaasgevind het. As die Afrikaanse Taalkommissie die Vereenvoudigde Hollandse Spelling gaan volg, bestendig hulle Hollands vir die Taalbond, en dan sal die Taalbond op sy beurt nie Langenhoven se voorstel oor die invoer van Afrikaans as skooltaal by die 1914 Akademiejaarvergadering teenstaan nie, en dan kan die standaardiseringsproses voortgaan.

Die pro-Nederlandse Taalbond het heelwat gebaat uit sy samewerking met die Langenhovenplan. Afrikaans is met hierdie eerste $A W S$ ingrypend vernederlands, en dié $A W S$ het in 'n hoë mate riglyne verskaf om 'n Vereenvoudigde Hollands te spel en te skryf. Vgl. Reël 11 van $A W S 1$ (naas ander sulke soortgelyke reëls) wou gehad het dat kinders soos in Hollands gespel word, desnieteenstaande die TK se eie waarneming, wat ook daar gedokumenteer is, dat die $-d$ - "in Afrikaans gewoonlik aan die voorafgaande klank gelijk gemaak word". Toe Langenhoven op die 3 Julie-vergadering gesê het daar mag nie aan die konsepspelreëls verander word nie, het hy die eerbiediging van die ooreenkoms wat hy voor die vergadering met die Taalbond aangegaan het, in gedagte gehad. Grondbeginsel 4 het die kern van daardie ooreenkoms bevat.

Daar is hierbo verwys na prof. Viljoen van die Taalbond se besoek aan Nederland en België in 1903 om 'n vereenvoudigde Hollandse spelling (VHS) vir Suid-Afrika te onderhandel. (Vgl. ook Odendaal 2012: 242, noot 9 wat die VHS-spelreëls van nader bekyk het.) Met Viljoen se terugkoms het die Taalbondkongres van 1904 daardie transaksie wat in Nederland en België aangegaan is, bekragtig, alhoewel daar geargumenteer is dat dit die ondersteuning aan "n tweede Nederlands" in Suid-Afrika sou beteken (Steyn 2017: 240). Dit was wel die geval, maar dit illustreer ook die drastiese stappe wat die voorstanders van Hollands in SuidAfrika geneem het om Hollands in Suid-Afrika te probeer vestig.

Vyftig jaar later, in die AWS 6 van 1953, met die herformulering van die grondbeginsel oor die Vereenvoudigde Nederlandse Spelreëls, het die Taalkommissie besluit om die gevolge van dáárdie besluit van die 1904-Taalbondkongres vir die latere spelling van Afrikaans openbaar te maak. Hulle het daardie grondbeginsel toe soos volg gestel: "Die Afrikaanse spelling wil aansluit by die Vereenvoudigde Nederlandse Spelling (VNS)", en die veelseggende toevoeging daarby was: "soos in 1904 in Suid-Afrika aanvaar". Daardie 1953toevoeging het verwys na die skatplig van die Akademie se Taalkommissie aan die Hollandse spelhervormers in Hollands en België waaraan die Taalbond-kongres van 1904 hom verbind het. Dit het deur die Langenhovenonderhandelinge Taalkommissieerfgoed geword. Le Roux is in 1953 weer verkies as TK-Voorsitter, en hy en Malherbe, wat sedert die eerste Taalkommissie daarvan lede was, het die greep van die Taalbond op daardie eerste 1917Taalkommissie onthou. Met die 1953-dokumentering daarvan, het hulle hulle moontlik ook daarvan probeer distansieer, in aansluiting by Le Roux se eerste paragraaf van die eerste Voorwoord van die eerste vernederlandste $A W S$ in 1917. Daarin verwelkom Le Roux nie die splinternuwe spellingwêreld wat $A W S 1$ vir Afrikaans sou oopmaak nie, maar hy skryf oor die Genootskap van Regte Afrikaners (GRA) van veertig jaar vroeër. Daardie GRA wat met voorbedagte rade van geskrewe Hollands af weggebly het. Het Le Roux daarmee alreeds tussen die reëls geprotesteer teen die Vereenvoudigde Hollands van AWS 1? 
Dit was hierdie grondbeginsel oor die Vereenvoudigde Nederlandse Spelling in AWS 6 (1953) wat aangedui het hoe slim sy baas gevang het. Langenhoven het goed geweet wat die verskil was tussen Afrikaans en Nederlands. Hy het daaroor 'n verdienstelike uiteensetting gegee in Die Brandwag van 1 April 1913. Maar om sy plan vir Afrikaans as skooltaal deurgevoer te kry, al was dit voorlopig net in naam, moes hy doodeenvoudig daarmee verlief geneem het dat die Taalbond hom met 'n spelreël gelaat het waarmee die $A W S$ eintlik Hollands gespel het. Hierdie grondbeginsel is eers in 1986 geskrap.

\section{Op'n skinkbord ...}

$\mathrm{Na}$ die Langenhoven-onderhandelings van 1914 moes die TK tussen 1915 en 1917 'n woordelys gereed kry waaraan die spelreëls geïllustreer kan word. Die VNS-woordeboeke van Elffers en Viljoen (1908) en Van Rijn (1908), was inderwaarheid op 'n skinkbord vir die samestellers van die woordelys aangebied. Hierdie VNS-woordeboeke is saamgestel uit Hollandse woorde wat alreeds volgens die Vereenvoudigde Hollandse Spelmanier (VHS) gespel is. Die Woordelijs-Kommissie van AWS 1 het inskrywings daaruit gerieflikheidshalwe net so vir sy nuwe woordelys gebruik, met geringe morfologiese aanpassings waar nodig. Woordeboekmakery is soms plagiaat in alfabetiese volgorde, het Gouws (2017) hom uitgelaat (met verwysing na 'n ander konteks).

In AWS 1 se woordelys staan daar talle Hollandse woorde (vgl. ook Odendaal 2016). Hulle kom net so in Elffers en Viljoen se 1908 woordeboek voor: auto, bigot (skynvroom), different, doorgaans, editeur, edukasie, faljiet (bankrot), fameus, felisiteer, femelaar (skynheilige), freule (adelike jonkvrou), goevernement, rekommandeer, relaksasie, vanille-ijs, en tutoyeer (om iemand met jy/jou aan te spreek).

Elffers en Viljoen het die Engelse woorde fancy-fair en auntie in hulle 1908-VHSwoordeboek opgeneem. Moontlik 'n fout. Die 1917-Woordelijs-Kommissie het dié twee woorde net so in AWS 1 oorgeskryf. Met sy Engelse spelling is auntie in AWS 3 geskrap, en ook fancy-fair. In AWS 11 (2017) is die ou Afrikaanse woord antie, met sy Afrikaanse spelling, 'n welkome toevoeging.

\section{Naskrif: die gevolge van die vernederlandsing van die $A W S$}

\section{1}

Verafrikaansing van die latere $A W S^{\prime}$ 'e is toenemend uitgevoer om die vernederlandsing van die eerste $A W S$ te probeer neutraliseer, soms teen groot teenstand in. Daar was egter so veel terreine waarop $A W S 1$ se Vereenvoudigde Hollands neerslag gevind het, waaronder in skoolmateriaal, tydskrifte en koerante, in die 1933-Bybelvertaling en in Afrikaanse woordeboeke, dat die Hollands van AWS 1 vir baie dekades nog bly vassteek het.

Die vernederlandse inskrywings van AWS 1 en 2 wat as Afrikaans voorgehou is, het die riglyn in die Afrikaanse normeringsomgewing na 1917 geword. Die Akademie het in 1914 'n komitee benoem (Akademiejaarboek V 1914: 26) om te verseker dat die Afrikaans van die skoolboeke wat gebruik gaan word, aan die $A W S$ se riglyne sou voldoen. Die $A W S$ se vernederlandse Afrikaans is in die hele Afrikaanse skryftaalwêreld nagevolg. Steyn (2014: 176) gee voorbeelde van 1933-Bybelafrikaans wat nog meer Nederlands bevat het as AWS 1 . 
Woordeboeke het steeds Nederlandsagtige inskrywings as Afrikaans voorgehou. Ponelis (1998: 67) verwys byvoorbeeld na die 1984-uitgawe van die Tweetalige woordeboek/Bilingual Dictionary waarin inskrywings voorgekom het soos: iets donker insien vir pessimisties wees, wat nie Afrikaans is nie, naas talle Nederlandismes waaronder iemand se voorbidding behoef (nodig het), belabberd (bedremmeld), dit benieu my (ontstel); beunhaas (kwaksalwer), ens., opnames waarna Gouws (2017) ook verwys het. Die eerste uitgawe van die woordeboek is in 1931 gepubliseer, en die bogenoemde woorde staan netso in die genoemde VHS-Nederlandse woordeboeke van 1908. Die 2005-uitgawe van die Pharos Afrikaans-Engels/English-Afrikaans Woordeboek/Dictionary, soos die woordeboek later bekend gestaan het, het nie meer so gelyk nie. Leksikonitems in die Vereenvoudigde Hollandse Spelling het op vrugbare Afrikaanse grond wortel geskiet, en Afrikaans se woordeskat lyk op die oog af baie soos Nederlands. Besoekers uit Suid-Afrika aan Nederland en België vind die ooreenkoms gou ontoereikend vir gesprekke en slaan dan desperaat oor na Engels toe. 'n Taal is meer as net sy woordeskat.

Alhoewel Afrikaans se $A W S$ 'e al hoe meer verafrikaans is, kon die vernederlandsing van Afrikaans deur die eerste $A W S$ é nie ongedaan gemaak word nie, nié in die $A W S$ é en ook nie in ander publikasies (soos bogenoemde woordeboek) waarheen vernederlandsing uitgekring het nie. Le Roux en Malherbe het met die eerste betekenisvolle verafrikaansings in AWS 3 begin, veral met die skrapping van wisselvorme van Afrikaanse woorde wat volgens die VHS spelling geskryf is. Van 1918 af het hulle die hulp van D. B. Bosman bygekry. J. J. Smith, die derde lid van die eerste TK, het heftig teen die graad van verafrikaansing weerstand gebied. Hy het in 1927 uit die TK bedank. Daar was meer vooraanstaande Afrikaanssprekendes wat hulle met 'n Afrikaans wou vereenselwig het wat 'n sterker Hollandse inslag vertoon het, en Preller het by 'n vroeëre geleentheid geskryf: "ons wil ons Hollands nie loslaat nie" (De Volksstem, 6 en 9 September 1905). Verafrikaansing was nie 'n eenvoudige taak nie. Binnegevegte oor hoeveel Nederlands behoue moes bly, en hoeveel daarvan verafrikaans moes word, het onder andere meegebring dat Afrikaans in die dertigerjare vir ses jaar prakties sonder 'n geldige AWS gelaat is (vgl. Bosman 1932).

$\mathrm{Na}$ die vyftigerjare het woorde wat op die Vereenvoudigde Hollandse manier gespel is, hulle eie betekenisfasette in Afrikaans begin kry. C. J. Conradie het in 2010 op sulke gevalle gewys (abstrakte selfstandige naamwoorde soos bedroë), in 'n studie wat oor ander sake gegaan het (onder andere Conradie 2010: 69). Verafrikaansing moes na verloop van tyd met toenemende omsigtigheid uitgevoer word.

\section{2}

Die verafrikaansings van bestaande inskrywings het die ingrepe wat die Taalkommissies op Standaardafrikaans kon maak, goed geïllustreer. Ander Taalkommissies kon geskrewe Afrikaans heeltemal anders laat lyk het, miskien meer soos Nederlands of moontlik meer soos Afrikaans. Die inhoud van AWS 1 kan nie 'n geldige beeld van Afrikaans skets nie. Die $A W S$ skrifbeeld is in 'n hoë mate 'n toevalligheid, waarby baie nie-talige faktore soos tradisie en vooroordele saamspeel, en waardeur die siening van Standaardafrikaans as een van Afrikaans se natuurlike variëteite bevraagteken kan word. 


\section{3}

Dikwels word inskrywings uit die $A W S$ gebruik om as bewys te dien dat Afrikaans uit Nederlands stam, maar dit is die reste van die eerste vernederlandse $A W S$ wat as bewysmateriaal gebruik word. In die lig van die mate van willekeurigheid wat die $A W S$ inskrywings onderlê, soos die wisselvallige besluitneming oor vernederlandsing / verafrikaansing, kan hierdie bewysmateriaal sekerlik nie geldig wees nie.

\section{4}

Die Achilleshiel van die $A W S$ 'e is die swak verteenwoordiging van die taal van die breë Afrikaanse spraakgemeenskap daarin. Dit kan deels teruggevoer word na die vernederlandsing van $A W S$ 1. Afrikaans se dialekvorme sou nooit in die Vereenvoudigde Hollandse standaardkode aanvaar word nie. Afrikaanse dialekvorme kon nie die statustoets wat die wêreld van die Vereenvoudigde Hollands spelling gestel het, slaag nie (vgl. AWS 1: v). Die rede kan egter net deels as 'n verskoning aangevoer word, want met die herstandaardiserings van AWS 3 en die verafrikaansings daarna, behoort die Afrikaanse Woordelys en Spelreëls meer van die totale Afrikaanse spraakgemeenskap se taal te gereflekteer het (vgl. Deumert (2004) oor die rol van taalgemeenskappe in sulke gevalle). Die Taalkommissies van AWS 910 en 11 se houding teenoor Afrikaans se dialekte en dialeksprekers het aanmerklik verander van die ingesteldheid wat hulle vroeë voorgangers geopenbaar het, en daar is spesiaal werk van gemaak om leksikale items uit die skryftaal van Moesliem-Afrikaanssprekendes in AWS 9 en 10 op te neem, en in AWS 11 'n aantal leksikale items uit Kaaps en Oranjerivierafrikaans. Maar was dit goed genoeg?

AWS 11 (2017) het die regte ding gedoen, en was die eerste AWS wat Afrikaans se dialekmateriaal prinsipieel as deel van die Afrikaanse taalgegewe erken het. Alle Afrikaanse woorde kan nou, ooreenkomstig opnamevoorwaardes, in die standaardkode ingeskryf te word. Dit het 100 jaar gevat, maar AWS 11 sal hiérvoor onthou word.

\section{Verwysings}

Akademie vir Wetenskap en Kuns. 1910 tot 1922. Akadmiejaarboek 1 tot XII.

AWS 1: T. H. Le Roux, D. F. Malherbe en J. J. Smith, in opdrag van die Suidafrikaanse Akademie vir Taal, Lettere en Kuns. 1917. Afrikaanse woordelijs en spelreëls. 1e uitgawe. Bloemfontein: Het Volksblad-Drukkerij.

AWS 2: T. H. Le Roux, D. F. Malherbe en J. J. Smith, in opdrag van die Suidafrikaanse Akademie vir Taal, Lettere en Kuns. 1918. Afrikaanse woordelijs en spelreëls. 2e uitgawe. Bloemfontein: De Nationale Pers.

AWS 3: D. B. Bosman, T. H. Le Roux, D. F. Malherbe en J. J. Smith, in opdrag van die Suidafrikaanse Akademie vir Taal, Lettere en Kuns. 1921. Afrikaanse woordelys en spelreëls. 3e uitgawe. Bloemfontein: Die Nasionale Pers. 
AWS 6: Taalkommissie (samest.), in opdrag van die Suid-Afrikaanse Akademie vir Wetenskap en Kuns. 1953. Afrikaanse woordelys en spelreëls. 6e uitgawe. Kaapstad, Bloemfontein \& Johannesburg: Nasionale Boekhandel.

AWS 9: Taalkommissie (samest.), in opdrag van die Suid-Afrikaanse Akademie vir Wetenskap en Kuns. 2002. Afrikaanse woordelys en spelreëls. 9e uitgawe. Kaapstad: Pharos.

AWS 10: Taalkommissie (samest.), in opdrag van die Suid-Afrikaanse Akademie vir Wetenskap en Kuns. 2009. Afrikaanse woordelys en spelrë̈ls. 10e uitgawe. Kaapstad: Pharos.

AWS 11: Taalkommissie (samest.), in opdrag van die Suid-Afrikaanse Akademie vir Wetenskap en Kuns. 2017. Afrikaanse woordelys en spelrë̈ls. 11e uitgawe. Kaapstad: Pharos.

Bosman, D. B. e.a. 1931/1936. Tweetalige woordeboek/Bilingual Dictionary. Kaapstad: Nasionale Pers.

Bosman, D. B. 1932. Lys van wysigings wat ingevolge die besluite van die Spellingkonferensie op Stellenbosch Januarie 1932, moet aangebring word in die Afrikaanse Woordelys en Spelreëls (4 de druk) van die S. A. Akademie vir Taal, Lettere en Kuns. Kaapstad: Nasionale Pers Beperk.

Bosman, F. C. L. 1959. Geskiedkundige oorsig van die Suid-Afrikaanse Akademie vir Wetenskap en Kuns. In Feesalbum 1909-1959. Pretoria: Suid-Afrikaanse Akademie vir Wetenskap en Kuns. pp. 73-166.

Burchell, W. J. 1967 [1822-1824]. Travels in the Interior of Southern Africa. London: Batchworth Press.

Conradie, C. J. 2010. Het Nederlands en die standaardisering van het Afrikaanse werkwoordssysteem. In M. an der Wal en E. Francken (reds.) Standaardtalen in beweging. Münster: Nodus Publikationen. pp. 67-84.

Deumert, A. 2004. Language standardization and language change. The dynamics of Cape Dutch. Amsterdam: John Benjamins.

Die samestellers van die Woordelijs. 1917. Die Afrikaanse spelreëls met aanvullinge. Akademie vir Wetenskap en Kuns. September. Bloemfontein: Het Volksblad-Drukkerij.

Elffers, H. en W. J. Viljoen. 1908. Beknopt Nederlands Woordeboek voor Zuid-Afrika. Kaapstad: J.C. Juta \& Co.

Giliomee, H. 2009. The Afrikaners. Cape Town: Tafelberg.

Gouws, R. 2017. Veelsydigheid en vernuwing in die werk van Fritz Ponelis. Ongepubliseerde Fritz Ponelis-gedenklesing. Stellenbosch, 27 Julie 2017.

Kannemeyer, J. C. 1995. Langenhoven. ’n Lewe. Kaapstad: Tafelberg. 
Kapp, P. 2009. Draer van 'n droom. Die geskiedenis van die Suid-Afrikaanse Akademie vir Wetenskap en Kuns 1909-2009. Hermanus: Hemel en see boeke.

Langenhoven, C. J. 1910. Padlangers en zonder doekies. Oudtshoorn: Het Zuid-Westen drukkerij.

Le Roux, T. H. 1926. Die geskiedenis van die Afrikaanse spelling. In Gedenkboek ter eere van die Genootskap van regte Afrikaners. Potchefstroom: Die Weste-Drukkery. pp. 256-277.

Nienaber, G. S. 1959. Die tweede Afrikaanse beweging. In Die Suid-Afrikaanse Akademie vir Wetenskap en Kuns, Feesalbum 1909-1959. Pretoria: Van Schaik. pp. 34-39.

Odendaal, B. G. 2012. Die herstandaardisering van Afrikaans. 'n Praktiese benadering met die AWS as gevallestudie. Proefskrif vir die graad Doktor in die Wysbegeerte aan die Universiteit van Stellenbosch.

Odendaal, G. 2016. Die rol van die US se Departement Afrikaans en Nederlands in die ontwikkeling van die Afrikaanse leksikografie: Die Nederlands-Afrikaans-stryd gedurende die aanvangsjare. Tydskrif vir Geesteswetskappe 56 (1): 257-281.

Ponelis, F. A. 1992. Standaardafrikaans in oorgang. In V. N. Webb (red.) Afrikaans ná apartheid. Pretoria: Van Schaik. pp. 69-89.

Ponelis, F. A. 1993. The development of Afrikaans, Frankfurt am Main: Peter Lang.

Ponelis, F. A. 1998. Standaardafrikaans en die Afrikaanse taalfamilie. Departement Afrikaans en Nederlands. (Annale van die Universiteit van Stellenbosch.) Goodwood: Nasionale Boekdrukkery.

Pretorius, F. 2012. Almal se oorlog: die Anglo-Boereoorlog (1899-1902). In F. Pretorius (red.) Geskiedenis van Suid-Afrika van voortye tot vandag. Kaapstad: Tafelberg. pp. 235-245.

Spies, S. B. 1968. Heropbou en unifikasie, 1902-1910. In C. F. J. Muller (red.) 500 jaar SuidAfrikaanse geskiedenis. Pretoria: Academica. pp. 323-343.

Steyn, J. C. 1980. Tuiste in eie Taal. Kaapstad: Tafelberg.

Steyn, J. C. 1989. Die taalstryd rondom Langenhoven, J.H. Malan en Het Zuid-Westen in 1910 en 1911. Suid-Afrikaanse Tydskrif vir Kultuur-en Kunsgeskiedenis 3(3): 217-225.

Steyn, J. C. 2014. Ons gaan 'n taal maak. Afrikaans sedert die Patriot-jare. Centurion: Kraal uitgewers.

Steyn, J. C. 2017. Die laaste projek van die "Hollandse taalbeweging in Suid-Afrika": die Vereenvoudigde Hollandse Spelling. Tydskrif vir Geesteswetenskappe 57(2-1): 233-248.

Van Rensburg, C. 2016. Die vroegste Khoi-Afrikaans. Tydskrif vir Geesteswetenskappe 56(21): 454-476. 
Van Rensburg, C. 2017a. Ná honderd jaar: Die Afrikaans van die eerste taalkommissie. Tydskrif vir Geesteswetenskappe 57(2-1): 249-270.

Van Rensburg, C. 2017b. Die totstandkoming van die eerste Afrikaanse woordelijs en spelreels. In Afrikaanse woordelijs en spelreëls. Faksimilee-uitgawe. Pretoria: Protea boekhuis. pp. 2-22.

Van Rijn, C. J. 1908. Dutch-English and English-Dutch Dictionary in the new spelling. Gouda: G B van Goor.

Viljoen, W. J. 1896. Beiträge zur Geschichte der Cap-Holländischen Sprache. Strassburg: Karl J. Trübner.

Zietsman, P. H. 1992. Die taal is gans die volk. Pretoria: Universiteit van Suid-Afrika. 